\title{
Molecular Characterization of Staphylococcus aureus Isolated from Renal Hemodialysis (HD) Patients from Saudi Arabia
}

\author{
Mohammed S. Al-Mogbel ${ }^{1}$, Fauwaz Al-Rashid ${ }^{2,3}$, Mamdoh Meqdam ${ }^{1}$, Hisham Al- \\ Ajlan ${ }^{4}$ and Mushtaq A. Khan ${ }^{1 *}$
}

${ }^{1}$ Molecular Diagnostic and Personalized Therapeutics Unit, College of Applied Medical Sciences, University of Ha'il, Kingdom of Saudi Arabia. ${ }^{2}$ King Khalid Hospital, Ha'il, Kingdom of Saudi Arabia. ${ }^{3}$ College of Medicine, University of Ha'il, Kingdom of Saudi Arabia. ${ }^{4}$ Prince Sultan Military Medical City, Riyadh, Kingdom of Saudi Arabia.

\begin{abstract}
Staphylococcus aureus, including methicillin resistant S. aureus (MRSA) is the most commonly isolated pathogen in hospitals worldwide. The aim of present study was molecular characterization of Staphylococcus aureus isolated from renal hemodialysis (HD) patients from Ha'il region of Saudi Arabia. A total of 392 samples were screened from 204 HD patients for colonization of $S$. aureus. The isolated bacteria were identified by MALDI-TOF-MS. Antibiotic susceptibility testing was performed using Microscan. Among these isolates, 72 S. aureus (43\% MRSA and 57\% MSSA) were identified.The isolates were considerably resistant with varied profile to the antibiotics tested except being $100 \%$ susceptible to vancomycin, linezolid and teicoplanin. Of the isolates, $22.2 \%$ were positive for biofilm assay. Four representative MRSA isolates were selected and whole genome sequence analysis was performed using MiSeq. Two out of the 4 MRSA were found to be ST-1 and 2 were found to be ST-32. Among MRSA isolates, $\mathbf{2 5 . 8 \%}$ were negative for mecA and all of them were negative for mecC gene. A high prevalence of MRSA in HD patients as well as high percentage of biofilm production in MRSA isolates highlights the vital role for standardized surveillance along with validated molecular typing methods to evaluate the incidence of MRSA and accordingly to control its spread.
\end{abstract}

Keywords: Hemodialysis, Staphylococcus aureus, Whole genome sequencing Pathogenic bacteria, MALDI- TOF-MS.

*Correspondence: drmushtaqkhan9@gmail.com; +966-580074075

(Received: 27 December 2018; accepted: 03 February 2019)

Citation: Mohammed S. Al-Mogbel, Fauwaz Al-Rashid, Mamdoh Meqdam, Hisham Al-Ajlan and Mushtaq A. Khan, Molecular Characterization of Staphylococcus aureus Isolated from Renal Hemodialysis (HD) Patients from Saudi Arabia, J Pure Appl Microbiol., 2019; 13(1):265-269 doi: 10.22207/JPAM.13.1.28

C The Author(s) 2019. Open Access. This article is distributed under the terms of the Creative Commons Attribution 4.0 International License which permits unrestricted use, sharing, distribution, and reproduction in any medium, provided you give appropriate credit to the original author(s) and the source, provide a link to the Creative Commons license, and indicate if changes were made. 


\section{INTRODUCTION}

Staphylococcus aureus is an opportunistic bacterial pathogen responsible for a large number of human and animal infections. Staphylococcus aureus is associated with asymptomatic colonization of the skin and mucosal surfaces of about $30 \%$ of normal humans ${ }^{1,2}$. The Staphylococcal infections have been found regularly among the patients with compromised immune system and when the skin or mucosal barriers are breached, following insertion of a foreign body ${ }^{3}$.

There is a high incidence of infections caused by $S$. aureus among the patients with renal disease; specifically, those undergoing hemodialysis or kidney transplantation ${ }^{4,5}$. Because of frequent use of antimicrobials for a prolonged time and use of catheters, the hemodialysis (HD) patients are at a higher risk of colonization and infection by multi-drug resistant $S$. aureus including MRSA (methicillin resistant $S$. aureus) $)^{6-8}$. The bacterial infections are the major cause of morbidity and mortality during receiving hemodialysis and S. aureus, particularly MRSA, is one of the most common pathogen ${ }^{9-11}$. Mortality from all causes in patients on dialysis treatment is 6.5-7.9 times higher than that of the general population. S. aureus can colonize almost half the dialysis population without any indication of disease ${ }^{12}$. However, such colonization of $S$. aureus can cause wound and tissue infections; septicemia; and chronic infections ${ }^{13-16}$.

Infections cause significant morbidity and mortality among dialysis patients and HD patients are a high-risk population for bloodstream infection ${ }^{17,18}$. Renal disease, especially hemodialysis is a complex health care issue globally, including Saudi Arabia. Saudi Center for Organ Transplantation (SCOT) estimated a total of 19,659 dialysis patients, 18,270 of them are treated by hemodialysis (HD) and the remaining 1,389 by peritoneal dialysis (PD) with the mortality of about $9 \%{ }^{19}$. There is a lack of data regarding the prevalence of $S$. aureus among hemodialysis patients from Saudi Arabia; therefore, the aim of present study was molecular characterization of Staphylococcus aureus isolated from renal hemodialysis (HD) patients from Ha'il region of Saudi Arabia.

\section{MATERIALS AND METHODS \\ Bacterial isolates}

In this study, a total of 392 samples were screened from 204 HD patients from King Khalid Hospital, Ha'il, Saudi Arabia. The samples were collected from catheter tips, catheter site swabs and nose swabs.

The identification of bacterial isolates was performed on MALDI-TOF-MS (Bruker Daltonics Germany) according to the manufacturer's guidelines. Briefly, a fresh bacterial colony from overnight culture was smeared on target plate overlaid with $1 \mu \mathrm{l}$ of a saturated a-cyano-4hydroxy-cinnamic acid (HCCA) matrix solution in $50 \%$ acetonitrile-2.5\% trifluoroacetic acid (Bruker Daltonics) with the help of a sterile toothpick and air dried at room temperature. The plate was loaded in to the machine and the operation was run. The identification and analysis of mass spectra were performed the MALDI Biotyper software package (version 3.0).

Identification and Antibiotic susceptibility by Microscan

Microscan walkaway (Siemens Healthcare Diagnostics, Sacramento, CA, USA); an automated system used for bacterial identification and antibiotic susceptibility test was used for confirmation of identification and antimicrobial susceptibility of the bacterial strains. In this method, a small portion of a well isolated colony was taken and added to a Gram-positive Microscan combo panel. The panel was loaded into the Microscan walkaway machine according to the

Table 1. Whole genome sequencing results showing MLST type 1

\begin{tabular}{|c|c|c|c|c|c|}
\hline \multirow[b]{2}{*}{ Gene } & \multicolumn{4}{|c|}{$\begin{array}{c}\text { Sequence Type: ST1 (MLST Scheme: } \\
\text { Staphylococcus aureus) }\end{array}$} & \multirow[b]{2}{*}{$\begin{array}{l}\text { Best } \\
\text { Match }\end{array}$} \\
\hline & $\begin{array}{c}\% \\
\text { identity }\end{array}$ & $\begin{array}{l}\text { Alignment } \\
\text { Lenght }^{3}\end{array}$ & $\begin{array}{c}\text { DB } \\
\text { Allele } \\
\text { Lenght }\end{array}$ & Gaps & \\
\hline $\operatorname{arcc}$ & 100 & 456 & 456 & 0 & arcc_1 \\
\hline aroe & 100 & 456 & 456 & 0 & aroe_1 \\
\hline glpf & 100 & 465 & 465 & 0 & glpf_1 \\
\hline gmk & 100 & 417 & 417 & 0 & gmk_1 \\
\hline pta & 100 & 474 & 474 & 0 & pta_1 \\
\hline tpi & 100 & 402 & 402 & 0 & tpi_1 \\
\hline yqit & 100 & 516 & 516 & 0 & yqit_1 \\
\hline
\end{tabular}


manufacturer's protocol. Results were available after 24- 48 hrs.

\section{Biofilm assay}

Biofilm assay was performed according to a previously published method ${ }^{20}$.

Polymerase Chain Reaction for mec genes

PCR was used to determine the type of mec gene in MRSA isolate ${ }^{21}$. The primers used for detection of types of mec gene were $F: 52$ -GTAGAAATGACTGAACGTCCGATGA-32 and R: 52 -CCAATTCCACATTGTTTCGGTCTAA-32 .

Table 2. Whole genome sequencing results showing MLST type 80

\begin{tabular}{|c|c|c|c|c|c|}
\hline \multirow[b]{2}{*}{ Gene } & \multicolumn{4}{|c|}{$\begin{array}{l}\text { Sequence Type: ST80 (MLST Scheme: } \\
\text { Staphylococcus aureus) }\end{array}$} & \multirow[b]{2}{*}{$\begin{array}{l}\text { Best } \\
\text { Match }\end{array}$} \\
\hline & $\begin{array}{c}\% \\
\text { identity }\end{array}$ & $\begin{array}{l}\text { Alignment } \\
\text { Lenght }^{3}\end{array}$ & $\begin{array}{c}\text { DB } \\
\text { Allele } \\
\text { Lenght }\end{array}$ & Gaps & \\
\hline $\operatorname{arcc}$ & 100 & 456 & 456 & 0 & arcc_1 \\
\hline aroe & 100 & 456 & 456 & 0 & aroe_3 \\
\hline glpf & 100 & 465 & 465 & 0 & glpf_1 \\
\hline$g m k$ & 100 & 417 & 417 & 0 & gmk_14 \\
\hline pta & 100 & 474 & 474 & 0 & pta_11 \\
\hline tpi & 100 & 402 & 402 & 0 & tpi_51 \\
\hline yqit & 100 & 516 & 516 & 0 & yqit_10 \\
\hline
\end{tabular}

A PCR amplicon of 310 base pairs was analyzed using Sanger sequencer.

\section{Whole Genome Sequencing}

The sequencing of the bacterial genome for detection of antibiotic resistant genes, virulence factors, plasmids and MLST types was performed by using Illumina methodology using NextEra kit for library preparation ${ }^{22}$. The presence of known acquired resistance genes was determined by mapping the data from the isolate to an online database. The ResFinder web server (www.genomicepidemiology.org) and Basespace from Illumina was used to identify acquired antimicrobial resistance genes, MLST types and the presence of different virulent genes in the WGS data, using a threshold of $98 \%$ identity.

\section{RESULTS AND DISCUSSION}

There is a high incidence of colonization followed by infections caused by $S$. aureus among the HD patients ${ }^{5}$. The main reason behind this high infection rate among HD patients is because of frequent use of antimicrobials for a prolonged time and use of catheters during the dialysis procedure. Thus HD patients are at a higher risk of colonization and infection by multi-drug resistant $S$. aureus including MRSA (methicillin resistant $S$.

Table 3. Whole genome sequencing results showing different antibiotic resistance genes and virulence factors

\begin{tabular}{|c|c|c|c|c|c|c|}
\hline $\begin{array}{l}\text { Reistance } \\
\text { Gene }\end{array}$ & $\begin{array}{c}\% \\
\text { Identity }\end{array}$ & $\begin{array}{l}\text { DB Allele/ } \\
\text { Alignment } \\
\text { Lenght }\end{array}$ & Contig ID & $\begin{array}{l}\text { Poistion } \\
\text { in Contig }\end{array}$ & Phenotype & $\begin{array}{c}\text { Accession } \\
\text { No. }\end{array}$ \\
\hline ant(6)-la & 100 & $909 / 909$ & $\begin{array}{l}\text { NODE_11_lenght_6968 } \\
\text { _cov_40.318600 }\end{array}$ & 2019..2927 & $\begin{array}{l}\text { Aminoglycoside } \\
\text { reistance }\end{array}$ & AF3300699 \\
\hline $\operatorname{aph}\left(3^{\prime}\right)-I I I$ & 100 & 795/795 & $\begin{array}{l}\text { NODE_11_lenght_6968 } \\
\text { _cov_40.318600 }\end{array}$ & $3559 . .4353$ & $\begin{array}{l}\text { Aminoglycoside } \\
\text { resistance }\end{array}$ & M26832 \\
\hline$m s r(\mathrm{~A})$ & 99.73 & $1467 / 1467$ & $\begin{array}{l}\text { NODE_10_lenght_6376 } \\
\text { _cov_88.807556 }\end{array}$ & $4297 . .5763$ & $\begin{array}{l}\text { Macrolide, } \\
\text { Lincosamide and } \\
\text { Streptogramin B } \\
\text { reistance }\end{array}$ & X52085 \\
\hline norA & 91.59 & $1167 / 1142$ & $\begin{array}{l}\text { NODE_15_lenght_25906 } \\
\text { _cov_27.324635 }\end{array}$ & 5508..6649 & $\begin{array}{l}\text { Fluroquinotone } \\
\text { reistance }\end{array}$ & M97169 \\
\hline mecA & 100 & $2007 / 2007$ & $\begin{array}{l}\text { NODE_84_lenght_8411 } \\
\text { _cov_30.187254 }\end{array}$ & $1736 . .3742$ & $\begin{array}{l}\text { Beta-lactam } \\
\text { reistance }\end{array}$ & AB 033763 \\
\hline blaz & 99.55 & $846 / 441$ & $\begin{array}{l}\text { NODE_480_length_434 } \\
\text { _cov_166.806458 }\end{array}$ & $\begin{array}{l}\text { 1/1/0441 } \\
\text { 12:00:00 AM }\end{array}$ & $\begin{array}{l}\text { Beta-lactam } \\
\text { reistance }\end{array}$ & AJ302698 \\
\hline fusB & 100 & $642 / 642$ & $\begin{array}{l}\text { NODE_30_lenght_2646 } \\
\text { _cov_44.031746 }\end{array}$ & 1364...2005 & $\begin{array}{l}\text { Fusidic acid } \\
\text { reistance }\end{array}$ & AM292600 \\
\hline
\end{tabular}


aureus $)^{6-8}$. The bacterial infections are the major cause of morbidity and mortality during receiving hemodialysis and S. aureus, particularly MRSA, is one of the most common pathogen ${ }^{9-11}$. The current study was aimed at characterization of $S$. aureus isolated from renal hemodialysis (HD) patients from Ha'il region of Saudi Arabia.

A total of $72 \mathrm{~S}$. aureus isolates were cultured from patients undergoing HD, and among these, $43.1 \%$ were MRSA and $56.9 \%$ were methicillin sensitive $S$. aureus (MSSA). Previous studies have highlighted a high percentage of $S$. aureus colonization among HD patients ${ }^{17,23,24}$. The percentage of MRSA and MSSA in our study was found similar to that of a study published from Japan $^{17}$. The antibiotic profiling of $S$. aureus is very critical in management of the serious infections among the hospitalised patients. The $S$. aureus isolates from our study showed a varied profile to the antibiotics tested with $100 \%$ susceptibility to vancomycin, linezolid and teicoplanin. In addition, the capability of biofilm production among $S$. aureus helps it to remain in the hospital environment for prolonged time period leading to colonization of more patients ${ }^{25}$. In our study, $22.2 \%$ S. aureus were positive for biofilm assay.

By using the most advanced technique in Microbiology laboratory, whole genome sequencing can provide a broad analysis of the bacterial strains from all the sources. With the development of bench-top sequencers and rapid analytical softwares, WGS has become a useful tool to guide treatment of the infections caused by bacterial strains. The whole genome sequencing results of MRSA from our study revealed that genome sizes ranging from 2879711 bp to 3012628 bp with 720 to 3408 contigs were successfully sequenced. The MLST data revealed that the most common MLST type of the MRSA from our study were ST1 and ST80 (Table 1 and Table 2). The res finder showed that the MRSA in our study contained the genes which exhibited the resistance to aminoglycosides, macrolides, fluoroquinolones, $\beta$-lactams and the most common genes detected were $\operatorname{msr}(A)$, norA, blaZ, ant(6)Ia, aph(3)-III, mecA and fusB (Table 3 ). The presence of these genes by WGS was found to be associated with that of phenotypic antibiotic profiles.

\section{CONCLUSIONS}

This is the first report of molecular characterization of $S$. aureus collected from HD patients in Ha'il region of Saudi Arabia. A high prevalence of MRSA in HD patients as well as high percentage of biofilm production in MRSA isolates were observed in this study. This study emphasizes on the vital role for standardized surveillance along with validated molecular characterization methods to evaluate the incidence of MRSA and accordingly to control its spread among HD patients.

\section{ACKNOWLEDGEMENTS}

This study was funded by King Abdulaziz City for Science and Technology (KACST), General Directorate of Research Grant 143-34.

\section{CONFLICT OF INTEREST}

The authors declare that there are no conflicts of interest.

\section{REFERENCES}

1. Pollitt, E.J.G., Szkuta, P.T., Burns, N., Foster, S.J. Staphylococcus aureus infection dynamics. PLoSPathog, 2018; 14(6): e1007112.

2. Wertheim, H.F., Melles, D.C., Vos, M.C., van Leeuwen, W., van Belkum, A., Verbrugh, H.A., Nouwen, J.L. The role of nasal carriage in Staphylococcus aureus infections. Lancet Infect. Dis., 2005; 5:751-762.

3. Crosby, H.A., Kwiecioski, J., Horswill, A.R. Staphylococcus aureus aggregation and coagulation mechanisms, and their function in host-pathogen interactions. Adv. Appl. Microbiol, 2016; 96: 1-41.

4. Rub'n Arturo Silvero Isidre., Acosta, F.R., Vargas, C.R.C., Romero, G.A.V., Perrota, J.F.P., Fretes, R.M.G. Molecular Characterization of Staphylococcus aureus Isolates Obtained from Hemodialyzed Patients at the Hospital de Clo nicas of Paraguay: A pilot study. Int. J Med Stud, 2017; 5(1):14-19.

5. Shinefield, H., Black, S., Fattom, A., Horwith, G,.Rasgon, S., Ordonez, J., Yeoh, H., Law, D., Robbins, J.B., Schneerson, R., Muenz, L., Fuller, S., Johnson, J., Fireman, B., Alcorn, H., Naso, R. Use of a Staphylococcus aureus conjugate vaccine in patients receiving hemodialysis. $N$. Engl. J. Med, 2002; 346:491-496.

6. Enright, M.C., Day, N.P.J., Davies, C.E., Peacock, S.J., Sprat,t B.G. Multilocus Sequence Typing for 
Characterization of Methicillin-Resistant and Methicillin-Susceptible Clones of Staphylococcus aureus. J Clin Microbiol, 2000; 38(3):1008-1015.

7. Saxena, A.K., Panhotra, B.R. The Prevalence of Nasal Carriage of Staphylo-coccus aureus and Associated Vascular Access-Related Septicemia Among Patients on Hemo-dialysis in Al-Hasa Region of Saudi Arabia. Saudi J. Kidney Dis. Transpl., 2003; 14(1):30-38.

8. Sanavi, S., Ghods, A., Afshar, R. Catheter associated infections in hemodialysis patients. Saudi J. Kidney Dis. Transpl., 2007; 18(1):43.

9. Churchill, D.N., Taylor, D.W., Cook, R.J., LaPlante, P., Barre, P. Canadian Hemodialysis Morbidity Study. Am J. Kidney Dis., 1992; 19: 214-234.

10. del Rio, A., Cervera, C., Moreno, A., Moreillon, P., Mirq, J.M. Patients at risk of complications of Staphylococcus aureus bloodstream infection. Clin. Infect. Dis., 2009; 48: S246-S253.

11. Bradley, J.R., Evans, D.B., Calne, R.Y. Long-term survival in haemodialysis patients. Lancet, 1987; 1:295-296.

12. Stern, A., Sachdeva, S., Kapoor, R., Singh, J., Sachdeva, S. High blood pressure in dialysis patients: Cause, pathophysiology, influence on morbidity, mortality and management. J. Clin. Diagn. Res., 2014; 8:,ME1-ME4.

13. Lowy, F. Staphylococcus aureus infections. N. Engl. J. Med. 1998; 339: 520-532.

14. Tong, S.Y., Davis, J.S,, Eichenberger. E., Holland, T.L., Fowler, V.G.Jr.Staphylococcus aureus infections: epidemiology, patho-physiology, clinical manifestations, and management. Clin Microbiol Rev, 2015; 28:603-661.

15. Ralph Corey, G. Staphylococcus aureus Bloodstream Infections: Definitions and Treatment.Clinical Infectious Diseases, 2009; 48(4): S254-S259.

16. Weems, J.J. Jr. The many faces of Staphylococcus aureus infection: recognizing and managing its life-threatening manifestations.Postgrad Med, 2001; 110: 24-31.

17. Imaizumi, T., Hasegawa, T., Nomura, A., Sasaki, S., Nishiwaki, H., Ozeki T., Shimizu, H., Minatoguchi, S., Yamakawa, T., Yazawa, M., Uchida, D., Kawarazaki, H., Miyamoto,
M., Suzuki, T.,Koitabashi, K., Furusho, M., Fujita, Y. Association between Staphylococcus aureus bacteremia and hospital mortality in hemodialysis patients with bloodstream infection: a multicenter cohort from Japanese tertiary care centers. Ther.Apher. Dial., 2017; 21:354-360.

18. Patel,P.R,,Kallen, A.J., Arduino, M.J. Epidemiology, surveillance, and prevention of bloodstream infections in hemodialysis patients. Am. J. Kidney Dis., 2010; 56:566-577.

19. Dialysis in the Kingdom of Saudi Arabia. Saudi J. Kidney Dis. Transpl., 2018; 29(4): 1012-1020.

20. Heilmann, C., Gerke, C., Perdreau-Remington., Go"tz, F. Characterization of Tn917 insertion mutants of Staphylococcus epidermidis affected in biofilm formation. Infect. Immun, 1996; 64:277-282.

21. Al-Abbas, M.A. Antimicrobial susceptibility of Enterococcus faecalis and a novel Planomicrobium isolate of bacterimia. International Journal of Medicine and Medical Sciences, 2012; 4(2): 19-27.

22. Tokajian, S., Eisen, J.A., Jospin, G., Farra, A., Coil, D.A. Whole genome sequencing of extendedspectrum $\beta$-lactamase producing Klebsiella pneumoniae isolated from a patient in Lebanon. Front Cell Infect Microbiol, 2015; 5: 32.

23. Dopirak, M., Hill, C., Oleksiw, M.,Dumigan, D., Arvai, J., English, E., Carusillo, E., Malo-Schlegel, S., Richo, J., Traficanti, K., Welch, B., Cooper, B. Surveillance of hemodialysis-associated primary bloodstream infections: the experience of ten hospital-based centers. Infect Control Hosp Epidemiol, 2002; 23:721-724.

24. Klevens, R.M, Edwards, J.R., Andrus, M.L., Peterson, K.D., Dudeck, M.A., Horan, T.C., NHSN Participants in Outpatient Dialysis Surveillance. Dialysis surveillance report: National Healthcare Safety Network (NHSN) - Data summary for 2006. Semin Dial, 2008; 21:24-8.

25. Archer, N.K., Archer, N.K., Mazaitis, M.J., Costerton, J.W., Leid, J.G., Powers, M.E., Shirtliff, M.E. Staphylococcus aureus biofilms: properties, regulation, and roles in human disease. Virulence, 2011; 2:445-459. 